\title{
Narrative Strategies in the Early Poems \\ by A.E. Kulakovskii \\ (The Oath of the Abaasy: \\ Establishing an Individual Poetry Style)
}

\author{
Lidia N. Romanova* \\ Institute for Humanitarian Research \\ and Indigenous Peoples of the North SB RAS \\ Yakutsk, Russian Federation
}

Received 24.10.2018, received in revised form 27.11.2018, accepted 07.12.2018

\begin{abstract}
The subject of our study is the narrative strategies in the early poetry of A.E. Kulakovskii, considered by the example of his first published work - Abaahy Andaghara (The Oath of the Abaasy). Being a free translation of an abstract from the poem by M.Y. Lermontov, this literary piece is an original work of art of the Yakut poet that defines the type of lyrical discourse as narrative.

The aim of the article is to single out features of the narrative strategies and how they manifest themselves in the creative work of the first Yakut poet, the founder of regional Yakut literature. The study sets the following the goals: to define methodological approaches in the study of the lyrical narrative aspects; to distinguish narrative instances in the poetic text under the study; to show the process of how the poetic genre has been established in the Yakut literature by the example of the syncretic text - the Oath of the Abaasy.

Based on the methodological principles of narrative research, the features of the narrative instance that organizes communication in the lyrical text, as well as the features of the formation of the narrative structure of the lyrical text are revealed. The syncretic nature of the composition of the work (combination of poetic and prosaic texts, narrative and performative discourses) became a starting point for the poet in defining narrative strategies, i.e. communicative possibilities (dialogics, the author's point of view), principles of narration based on the olonkho folklore storytelling traditions, as well as antinomy as a text-organizing artistic technique, etc.

Conclusions and other final remarks made in the article could serve as a basis for an indepth study of the specifics of the formation of a lyrical principle in national young and new-written literature, and for theoretical and methodological developments that reveal specific features of narration in a lyrical text.
\end{abstract}

Keywords: lyric principle, lyric narrative, author's self-consciousness, syncretic form, verse and prose.

(C) Siberian Federal University. All rights reserved

* Corresponding author E-mail address: litved@mail.ru 
Research area: philology.

Citation: Romanova, L.N. (2018). Narrative strategies in the early poems by A.E. Kulakovskii (The oath of the Abaasy: establishing an individual poetry style). J. Sib. Fed. Univ. Humanit. Soc. Sci., 15(4), 515-523. DOI: 10.17516/1997-1370-0358.

\section{Introduction}

One of the key problems in the study of the national poetry origin still remains the question of how the individual creative art forms and the poetic features were formed and how they established themselves. This issue is especially compelling for the researchers of the early and new-age literature, in which the poetic genres formed in accordance with unique rules, justified by the active correlation of the living oral traditions and the foreign literature experience.

A key factor in the establishment of the poetic art is the specific features of the author's worldview; hence, the initial question in the study of the poetic origin is the description of culture-related mechanisms of establishing and forming the authorship categories.

The formation of authorship and the poetic creative features in the Yakut literature is connected, first of all, with the name of the founder of Yakut literature, Aleksei Eliseevich Kulakovskii, whose poetry became largely known at the beginning of the $20^{\text {th }}$ century in its oral and written forms.

In the early period of his creative writing, before his works began to be published, he focused on works that were created for performers and listeners; they were put into a song form. There are several justifications for this: first of them is that his early works were published under the traditional title The Songs Sung by Kulakovskii (Y.'yllaabyt yryata'); second of them is the archive findings that were preserved up to this day and that represent "recorded words" in the archive notebooks by Z.V. Lukovtsev", N.A. Makarov², S.A. Novgorodov ${ }^{3}$, etc. This proves the theory that during the times of his oral and written work creation, the author and

\footnotetext{
1 Archive of the Yakut Scientific Centre of SB RAS. F. 4., op. 26, d. 19.

2 Archive of the Yakut Scientific Centre of SB RAS. F. 4., op. 26., ed. xp. 28., p. 38-47.

3 Archive of the Yakut Scientific Centre of SB RAS. F. 4., op. 9 , ed. xp. 47 , p. 29 ob. -30 ob.
}

creator of the first poetic text already used the name we know today.

At the same time, in his creative outlook, Kulakovskii was searching for genre forms aimed at the readers, not a single or a local, but a mass reader. The poet worked on the written representations of his creative writings and prepared them for publishing; in the process of publishing, the creative material was refurnished in terms of its unity in form and content. This shows that the author consciously took these specific steps in creating the poetic text.

\section{Research problem}

His first printed work depicting the Yakut poetic traditions was published in 1908, when his poem The Oath of a Demon (a translation of an extract from M.Iu. Lermontov's Demon) was published in the Yakutskaya Rech' (Yakut Speech) newspaper. Later that year, his poem Cursed Before Birth was published, another poem - A Large Fire-Breathing Boat - was published in 1913. Publications of his early works clearly demonstrate the process of his transitioning "from a singer to a poet", where the author of a literary work begins to fully replace the singer of the oral folk art.

Selection of early creative works out of the numerous poems created by Kulakovskii for publishing is also not accidental. The translation of an extract from Russian classics and poems that genetically refer to folklore texts initially demonstrate the inner potential of the establishing Yakut poetry, which, in its turn, adopted all the best traditions of the oral poetic and classic literary tradition. The first Yakut poet introduced himself to the public not only as the author of several poems, but also as the establisher of a poetic tradition, setting the deep genetic roots of the national poetry being formed.

Moreover, it should be mentioned that in his first creative works, the author established a 
special type of a poetic text aimed at narration, which would later become his signature style encompassing his entire creative path.

Considering the fact that the synthesis of epic and poetic mechanisms for text creation play an important role in Kulakovskii's poetry, in which narration performs one of the main text-forming functions, the analysis of his poetry as a poetical narrative system allows giving a new perspective of his creative principles and reading his poetic texts.

In this regard, his first published work The Oath of the Abaasy represents the greatest interest; the structure of this creative piece of writing combines two opposite forms of fictional narration - verse and prose; this demonstrates that there was a process of developing a narrative strategy in the early creative writings of the first Yakut poet.

\section{Methodology of the research}

According to V.I. Tiupa, poetic texts contain "images of all types of discourse - iterative, performative, narrative and mimetic" (Tiupa, 2009: 14). The narrative character of his poetry has been one of the contemporary and popular topics of study in literature, linguistics and theory of culture within the last two decades.

The problem of narration as an organizing structure form of the poetic text was mentioned in the scientific researches of Russian literary studies experts: V.M. Zhirmunskii (1973), Silman (1977), Korman (1978), Ginsburg (1974), Broitman (1997). Recently, there have been a number of researches carried out by a literary studies expert A.A. Chevtaev (2006). There are productive researches on the poetic narration as a means of expressing the author's worldview (Charkin, 2016). There also have been new studies on the problem of expressing the author's worldview in narrative poetry in general connection to the cognitive functions of language (Tataru, 2008). However, the special narration features in poetic and lyrical epic creative writings still have not been thoroughly studied and the narrative aspect, as a text-forming element of the lyrical text, is often regarded as a subsidiary aspect.
This aspect is especially well-represented in the study of the early and newly-written literature development; many of these forms of literature are genetically related to the oral written and narrative folklore, and to the traditional heroic epic, in particular, where the series of events serve as a text-forming basis of the epic storyline.

In Yakut literary studies, the problem of narration in poetic texts was first introduced by N.V. Pokatilova (2011; 2015). Her work regards the process of forming the poetic features in Kulakovskii's creative writing "as a model of forming a practically new form of authorship", in which "there is a special type of a narrative strategy of epic origin" (Pokatilova, 2015: 83). The mentioned approach in the researcher's scientific works allows considering the creative writings of the first Yakut poet from the point of view of methods of expressing the author's worldview in poetry through the narrative categories.

In order to single out the narrative strategies in Kulakovskii's poetry, it is possible to apply the methodological principles of modern narration studies that were largely developed within the scope of epic genre studies; however, they are applicable and quite productive in the analysis of poetic and epic poetic texts.

The study of this problem is based on the methods of narrative analysis of the literary text; these methods were developed in the works by Gerard Genette (1998), Joseph Prince (2006), Wolf Schmid (2003) and others. These scholars claimed that the narrative nature of the text is the structure-forming principle of any discourse; there were other distinguished scholars, such as B.A. Iusepenskii (1970) who defined the multi-layer nature of a "point of view" in the narrative text; V.I. Tiupa (2013) who proved the multi-plane types of poetic discourse. The theoretical grounds for the research are also the conceptual dogmas represented in the works by Iu.M. Lotman, M.M. Bakhtin, B.O. Korman, L.Ia. Ginzburg, S.N. Broitman, etc.

The method of narrative analysis undermines reading, interpretation and analysis of the poetic texts by Kulakovskii through the distinction of a multi-layer narration structure of the 
text, in which "the narrator and the naratator ${ }^{4}$ are inside an author-reader communicative system which is external in relation to them" (Schmid, 2003: 118).

\section{Discussion}

\section{Syncretic form of the Oath of the Abaasy by Kulakovskii: the author's choice of a narrative strategy}

Kulakovskii's works published during his early career, such as The Oath of the Abaasy (1908), Cursed Before Birth (1908), A Large Fire-Breathing Boat (1913) were initially filled with a form of lyrical narration. Each of these texts (as well as the majority of the forthcoming ones) contains in their foundation some kind of a mental event that is spiritual in its essence revealing the author's position towards values and his lyrical personality. The first published texts are the act of the poet's self-determination and an aesthetic guideline throughout his entire creative path.

Kulakovskii first published Abaaghy andaghara (The Oath of the Abaasy) in 1908 under the pseudonym Akula ${ }^{5}$ in the Yakut newspaper Sakha Sangata (Yakut Speech). It was one of the first translations of a poetic text from Russian to Yakut in the history of Yakut literature. The Yakut author translated an extract from M.Iu. Lermontov's Demon. The creative writing was fairly defined by the author as "a free translation": while preserving its mood and meaningful content, the main plotline, the main images of Lermontov's poem, it clearly shows the presence of the author in its compositional and stylistic structure of the translation; these last features were predetermined by the aesthetic principles of the author himself.

The Byron-inspired poem by M.Iu. Lermontov holds its special place in Russian literature as a classic example of romantic narration put in a poetic form. The narrative strategy became a text-building foundation for the Yakut translation as well.

It must be mentioned that the first draft of Lermontov's Demon made in 1829 , contained

\footnotetext{
A term introduced by Schmid $-T$.

5 Rus. Shark - T.
}

92 lines and a brief prose-form summary of the poem, which basically summarizes the plotlines of all the previous versions (Lermontov, 1989). This fact could hardly have been known to the Yakut poet due to the fact that the first version of Lermontov's text was not published; however, this speaks in favour of the justification and creative rationale for the compositional structure of the translation, which was instinctively chosen by Kulakovskii.

In this poem, the Yakut poet quite consciously invents a new creative form, the aesthetic effect of which is in the combination of two various form of fiction speech - poetic and prosaic. Such a choice in the combination of the given text was largely motivated by the preceding poetic tradition - oral autochthonic (epic and ritual) and literary (for example, a tendency to shift and mix genres in poetry of the Russian $19^{\text {th }}$ century, for instance, in the Pushkin's translations of Byron's texts).

The prose part of the Kulakovskii's text is a free interpretation and recompilation of the plot in Lermontov's poem and it serves as a frame for the poetic text. In order to achieve an equivalent poem translation, the Yakut poet chose the part of Demon's monologue, in which he gives an oath of love to Tamara. Out of the 90 lines from the Demon's monologue, the poet translates 32 lines and forms them into 34 poems (giving an almost word-by-word translation). He also added 14 poems containing repetitions of the key word andaghayabyn: in the original text, the word klyanus' ("I swear") is repeated at the beginning of each line 10 times. In the Yakut version, the word klyanus' is written on a separate line.

Despite the fact that the combined forms of speech serve as equal components of the complex text, Kulakovskii's creative piece of writing is rightfully regarded as poetic. The text is built in such a way as to highlight the Demon's direct speech not only as an important meaningful component of the storyline, but also as a rhythmically and graphically formed part of the text. The poetic part contains a significantly important representation of laws of the poetic text structure; these laws are very important to Kulakovskii as the creator of the Yakut poetic tradition. 
With this in mind, the prose part of the storyline, in terms of its style of description, rich diversity and the inner rhythmic structure, does not interrupt the unity and harmony of the text. The prose-poetic form does not in any way speak in favour of the text discretion or the unevenness of both parts of its structure. The dialogue nature of the two forms contained in a somewhat dramatic form of the poem allows it to be a complete and meaningful text and gives it epic uniqueness.

To some extent, the combination of the prose and poetic forms in Kulakovskii's text brings it closer to the syncretic structure of the Yakut olonkho, in which there is interplay of the spoken and chanted text. The text is characterized by a strict sequence of interplays of the epic storyline: the prose text unravels the sequence of events (thus, forming a plot structure), and expresses the characters' speech in the poetic form. As a result of their clash in the inner structure of the text, the story expands in its content, which includes all that is incompatible from the point of view of a traditional lyrical text - a combination of the narrative and anarrative (performative) discourses.

In the non-poetic narrative part, the poet uses principles of unfolding a storyline that are typical for the epic genre - a strict chronological narration where there is a logical sequence of the narrator's "words", which is supported by linking expressions of epic origin: "ol ihen", "onu koron baran", "sol kunten", "ol buola syldzhan" meaning "after this", "then", "since that day"; the characters' speech motivation (Tamara and the Demon); the use of retardation devices (repetition of the word "klyanus"'), formula expressions and linguistic constructions, which help to reproduce the mythological time and space, as well as the three-dimensional model of the world.

N.V. Pokatilova indicates that the rhythmic structure of a part of the text traditionally referred to as "the indicated poetic", "appears to be more complex and, apparently, has not been clearly defined yet" (Pokatilova, 2010: 31). In fact, the poem's tendency towards becoming a prose creates a complex rhythmic and graphic construction. There appears such a form, which Iu.N. Tynianov called a poem bordering with prose, or vers libre (Tynianov, 2010: 53)

A changing metrical and rhythmical poetic form in Kulakovskii's creative writing is significantly different from the original. Lermontov's non-verse poems acquired a different graphic representation due to the fact that the initial word klyanus' was singled out in a separate line in their Yakut version. Singling out the repeated key word allowed all the following lines to build in accordance with the principle of syntactic parallelism, where an important text-forming role is played by the alliterative horizontal assonance. A moderate and expanded, syllabic 16-18-line Yakut text, where the lexical plane unfolds owing to set expressions that originate from the oral poetic tradition and phrasal synonymy, and transforms the dynamic speech of Lermontov's character.

The research has shown that "the festive oath of the Demon is a true reflection of all the vital contradictions and it is based on antitheses", where "any value is immediately balanced by its antipode and every feeling is prepared to transform into its counterpart" (Pulkhritudova, 1964: 78). V.E. Vatsuro, who specialized in researching the poet's creative writing, also noted that "Lermontov delivers his thoughts through the use of antitheses" (Vatsuro, 1989: 361). Antonymy becomes a text-structuring form for Kulakovkii's translation as well. Interestingly, the binary opposition and the romantic dual verse concept becomes the most important ideological and aesthetic principle of many other works created by the Yakut poet later in his career.

The author does not shift aside from the content of Lermontov's oath and follows the same sequence of stating the moral values that define the life-changing and conscious event in the life of the main character - rejection of all the values he previously had. However, the grammatical "inconsistence" in the temporal plane of the poetic storyline, as well as the imagery and lexical unity of the valuable "objects" mentioned earlier, through which the archetype layer of the autochthonic culture is clearly visible, makes the text of the oath a genuinely "Yakut" text and an original one in terms of authorship. 
Moreover, the text is closely connected to the verbal expression of a Yakut ritual and a magical ritual - an andaghar oath pronounced before the aiyy deities and the sacred fire. The implicit connection of Lermontov's oath to the text of the Yakut andaghar can be traced in the work that Kulakovskii wrote later in his career - Bylyrgy sakha andaghara ("An Ancient Yakut Oath") that was completed in 1923.

The text mentioned above is also built on the basis of using antonymy that encompasses a wide range of moral and valuable representations of the Sakha people. In this respect, the oath that Kulakovskii chose for his translation, the Oath of the Demon, acquires a deeper meaning that reflects the cultural mind set of the poet towards rethinking the unity and the universal character of the world.

\section{Narrative instances in the text}

Despite the lack of a first-person point of view in the storytelling process, due to its generally emotional and expressive nature in the speech, which expresses the author's attitude towards the lyrical situation and despite the use of emotionally-coloured vocabulary describing the characters, the text is perceived as a point of view of an author/storyteller and a creative process of a lyrical storyteller.

It was important for Kulakovskii to retain the dialogue nature of the original text: moving from a real dialogue form (with an impersonal storyline of an implicit storyteller in combination with the characters' direct speech) to an inner dialogue nature of the text (an implicit orientation towards a reader/recipient in the storytelling non-poetic part; the inner dialogue form speech of the Abaasy).

Thus, the text contains several points of view that are in dialogue relation to each other throughout the text: the point of view of the narrator and "non-native speech" (voices) of other characters, which are dually directed towards the inner and exterior text reality (orientation towards the reader).

In the general context of the literary work under the study, the direct speech of the Abaasy (the poetic part) is presented as a citation of a "non-native speech", however, this representation of the axiological beliefs that define the se- mantic components structure implicitly transfers the storytelling instance of the work to the auctorial "non-native" speech of the character, and further turns the auctorial speech into the author/storyteller point of view.

Generally, the storytelling instances of the work predefined the communicative status of the text, as well as its complex subject-object structure and the dialogue nature as a text-forming foundation. According to Bakhtin, in the text, an external communicative link is responsible for the dialogue structure of the two subjective components: "the author and the one who understands" (Bakhtin, 1986: 388), in which the one who understands is, first of all, the reader who is not fully acquainted with the original text (a prose version of Lermontov's poem and its major content); secondly, it is the reader who is prepared and equipped with the oral poetic tradition necessary to perceive the literary text, which has common features with the epic forms of olonkho-telling and magic ritual texts (the andaghar oath); and, thirdly, the reader who has an understanding of the laws of creating poetic texts (it is largely known that by that time there were plenty of educated people among the Yakut intelligentsia who were trying their hand at creative writing).

An inner communicative act that manifests itself in the inner textual discourse: in the interconnections of the author/storyteller with the characters, which are explained in the text as well as in the correlations of the "native" and "non-native" speeches and the inner dialogue speech of the characters.

In general, despite its direct reference to the "non-native" text, Kulakovskii's story is a manifestation of value principles expressed from the point of view of the author. A somewhat inclination from the meaningful concept of the original depicted in the Yakut translation speaks in favour of the latter. While in Lermontov's poem, according to V.E. Vatsuro, "the character's struggles are an important concept feature of the poem" (Vatsuro, 1989: 360), the poem by Kulakovskii focuses on a completely different important feature - the content of the oath that represents the value standards of human existence. 
The contradictory nature of the Demon, his inner struggle and suffering, the depth of his feelings for Tamara are not represented in Kulakovskii's version. In the original Lermontov text, the confession and oath of the Demon are inseparable components for the understanding of the image of the poetic character; the confession explains and motivates the rebellious nature of his personality.

The mere absence of the Demon's confession in Kulakovskii's version significantly changes the ideological concept of Lermontov's text, in which, as had been mentioned above, an important and meaningful component is the complex and contradictory image of the poetic character. For the Yakut poet, it was essentially important to focus the reader's attention to the text of the oath that contains generally accepted dogmas, both valuable and structural.

\section{Conclusion}

Kulakovkii's first published work represents a structure that predetermines an ex- isting balance between the storytelling and the performative discourses with the dominating constructive and text-forming role of the first component. A combination of the prose and poetic forms of creative speech, the narrative and non-narrative discourses builds a text based on the principles close to the epic olonkho storytelling.

Creating a syncretic form of his work, Kulakovskii consciously aimed at the correlation and a balanced interpretation of these two components in the minds of the readers, when he published these works that form a textual unity.

In the early period of creative writing, Kulakovskii chose the narrative discourse among all others; it is precisely this discourse that coincides with the anthropological trends of his creative consciousness. His first published work, where he combined various lyrical discourses, clearly demonstrates $\mathrm{Ku}$ lakovskii's process of developing narrative poetry strategies.

\section{References}

Bakhtin, M.M. (1986). Estetika slovesnogo tvorchestva [The Esthetics of Language Arts]. Moscow, Iskusstvo Press, 445 p.

Broitman, S.N. (1997). Russkaia lirika 19-nachala 20 veka v svete istoricheskoi poetiki: sub'ect-obraz-struktura [Russian Lyrical Poetry of the $19^{\text {th }}$ Century and Early $20^{\text {th }}$ century]. Moscow, RGGU, 305[2] p.

Charkin, V.V. (2016). Liricheskii narrativ kak sposob vyrazheniia avtorskogo soznaniia v lirike S.Ia. Nadsona. Uchenye zapiski Orlovskogo gosudarstvennogo universiteta [Lyrical Narrative as a Method of Expressing the Author's Consciousness - S.Ia. Nadson's Lyrical Poetry as a Case-Study. Scientific Notes of the Oryol State University]. 01(70), 141-145.

Chevtaev, A.A. (2006). Povestvovatel'nye strategii v poeticheskom trovchestve Iosifa Brodskogy: avtoreferat dissertatsii na soiskanie uchenoi stepeni kandidata filologicheskikh nauk: 10.01.01 [Narrative Strategies in the Poetic Art of Iosif Brodsky: Abstract of a PhD thesis: 10.01.01]. Chevtaev Arkadii Aleksandrovich. Saint-Petersburg, $21 \mathrm{p}$.

Ginsburg, L.Ia. (1974). O lirike [On Lyrical Poetry]. Moscow: Sov. Pisatel Press, 408 p.

Genette, G. (1998). Figury. Raboty po poetike [Figures of Speech. Works on Poetics]. Moscow, Sabashnikov Press.

Iuspenskiy, B.A. (1970). Poetika kompozitsii: struktura khudozhestvennogo teksta i tipologiia kompozitsionnoi formy [Compositional Poetics: The Structure of the Literary Text and Typology of the Compositional Form]. Moscow, Iskusstvo Press, 224 p.

Korman, B.O. (1978). Lirika Nekrasova [Lyrical Poetry by Nekrasov]. Izhevsk, Udmurtia Press, 247 p.

Lermontov, M.Iu. (1989). Polnoye sobranie stikhotvorenii v 2 tomakh [Complete Collection of Poems in Two Volumes]. Leningrad, Sovietskii Pisatel' Press, Leningrad subdivision, 519-526.

Pokatilova, N.V. (2010). Ot ustnoi traditsii k pismennoi rannei literature [From the Oral Tradition to the Early Written Literature]. Novosibirsk, Nauka Press, 248 p. 
Pokatilova, N.V. (2011). K postanovke problemy genezisa liricheskogo nachala v literature: opyt rassmotreniia odnoi poeticheskoi traditsii. Filologicheskie nauki. Voprosy teorii i praktiki [On the Problem of Lyrical Genesis in Literature: the Experience of Reviewing One Poetic Tradition. Philological Sciences. Theoretical and Practical Aspects]. 4(11), 134-137.

Pokatilova, N.V. (2015). Epos i ranniaia literatura: narrativnye aspekty vzaimodeistviia [Epic and Early Literature: Narrative Aspects of Interaction]. In Sibirskii philologicheskii zhurnal [Siberian Philological Journal], (3), 81-87.

Prince, Gerald (2006). Narratologie classique et narratologie post-classique. Available at: http:// www.vox-poetica.org/t/articles/prince.html

Pulkhritudova, E. (1964). "Demon" kak philosophskaia poema. Tvorchestvo M.Iu. Lermontova: 150 let so dnia rozhdeniia, 1814-1964 ["Demon" as a philosophical poem. The Creative Writing of M.Iu. Lermontov: 150Years Anniversary 1814-1964]. Moscow. In Nauka Press, 76-105.

Schmid, V. (2003). Narratologiia [Narratology]. Moscow, Languages of the Slavic Culture, $304 \mathrm{p}$.

Silman, T.I. (1977). Zametki o lirike [Notes on the Lyrical Poetry]. Leningrad: Sovetskii Pisatel' Press. Leningrad subdivision.

Tataru, L.V. (2008). Prostranstvennaia tochka zreniia i struktura povestvovatel'nogo teksta: lingvo-kognitivnyi aspekt. Filologicheskie nauki [A Spacial Point of View and the Narrative Text Structure: Linguistic and Cognitive Aspects. Philological Sciences]. (1), 35-45.

Tynianov, Iu.N. (2010). Problema stikhotvornogo iazyka [The Problem of a Poetic Language]. Moscow, KomKniga Press, 176 p.

Tiupa, V.I. (2013). Diskurs/zhanr [Discourse/genre]. Moscow, Introada Press, 212 p.

Vatsuro, V.E. (1989). Lermontov. Istoriia vsemirnoi literatury [Lermontov. The History of World Literature], Vol. 6. Moscow, $361 \mathrm{p}$.

Zhirmunskii, V.M. (1973). Tvorchestvo Anny Akhmatovoi [The Poetry of Anna Akhmatova]. Leningrad: Nauka Press, 184 p. 
Повествовательные стратегии

ранней лирики А.Е. Кулаковского

(“Клятва Абаасы":

становление лирического начала)

\author{
Л.Н. Романова \\ Институт гуманитарных исследований \\ и проблем малочисленных народов Севера СО РАН \\ Российская Федерация, Якутск
}

\begin{abstract}
Аннотация. Предметом исследования являются повествовательные стратегии ранней лирики А.Е. Кулаковского, рассмотренные на примере первого опубликованного произведения «Абааһы андаБара» («Клятва Абаасы»). Произведение, будучи вольным переводом фрагмента поэмы М.Ю. Лермонтова, представляет собой оригинальное авторское произведение якутского поэта, в котором определился тип лирического дискурса как нарративного.

Цель статьи - выявить особенности становления повествовательных стратегий в творчестве первого якутского поэта, основоположника национальной литературы. Задачи исследования: определить методологические подходы в изучении специфики лирического нарратива; установить особенности повествовательных инстанций в исследуемом лирическом тексте; показать процесс становления лирического начала в якутской литературе на синкретичном тексте «Клятвы Абаасы».

$\mathrm{C}$ опорой на методологические принципы нарративного исследования выявлены особенности нарративной инстанции, организующей коммуникацию в лирическом тексте, особенности становления повествовательной структуры лирического текста. Синкретичность композиции произведения (сочетание стихотворного и прозаического текстов, нарративного и перформативного дискурсов) стала для поэта отправной точкой для определения повествовательных стратегий - коммуникативных возможностей (диалогичность, выражения авторской позиции), принципов наррации, исходящих из традиций эпического повествования олонхо, антиномичности как текстоорганизующего художественного приема и т.д.

Выводы и заключения, сделанные в статье, могут послужить для углубленного изучения специфики становления лирического начала в национальных младо- и новописьменных литературах и для теоретико-методологических разработок, выявляющих специфические черты наррации в лирическом тексте.
\end{abstract}

Ключевые слова: лирическое начало, лирический нарратив, авторское самосознание, синкретичная форма, стих и проза.

Научная специальность: 10.00 .00 - филологические науки. 